\title{
FLORISTIC COMPOSITION AND ABUNDANCE IN FOREST FRAGMENTS: A CASE STUDY FROM SOUTHERN GOIÁS, BRAZIL
}

\author{
COMPOSIÇÃO FLORÍSTICA E ABUNDÂNCIA EM FRAGMENTOS FLORESTAIS: \\ UM ESTUDO DE CASO NO SUL DE GOIÁS, BRASIL
}

\author{
Narcisa Silva SOARES ${ }^{1}$; Carlos André GONÇALVES ${ }^{2}$; Glein Monteiro ARAÚJO³ \\ Cecília LOMÔNACO
}

1. Professora, Doutora, Curso de Ciências Biológicas, Instituto Luterano de Ensino Superior de Itumbiara - ILES/ULBRA, Goiás, Brasil.narcisassoares@ gmail.com; 2. Professor, Mestre, Instituto Luterano de Ensino de Superior de Itumbiara - ILES/ULBRA; 3. Professores, Doutores, Instituto de Biologia, Programa de Pós-Graduação em Ecologia e Conservação de Recursos Naturais, Universidade Federal de Uberlândia, Minas Gerais, Brasil.

\begin{abstract}
The fragmentation of tropical forests has been identified as the main reason for their biodiversity reduction. This process is extensively occurring in the Brazilian central area, where there still are insufficient information about the remaining flora and fauna of the Neotropical Savanna and Atlantic Forest ecotone. This study aimed to determine the floristic composition and the abundance of the arboreal and subarboreal components of four semideciduos forest fragments. The data indicates that the floristic richness is positively influenced by the fragment area. However, the proximity between fragments has no influence on their floristic composition. It was recorded 126 species belonging to 91 genera distributed in 43 families, with the dominance of Siparuna guianensis Aubl. in all fragments. More than half of the total number of species of the arboreal stratum was not recorded in the subarboreal stratum. In addition, the subarboreal stratum also presented exclusive species. A high number of unique species was also recorded in each fragment, which emphasizes the importance of these remnants conservation, regardless of their sizes and indicates the need to create a management plan to promote connectivity between these fragmented areas.
\end{abstract}

KEYWORDS: Plant Diversity. Neotropical Savanna. Atlantic Forest. Floristic Similarity.

\section{INTRODUCTION}

The fragmentation of the native tropical forests generates many negative impacts on the structure and dynamics of diverse populations over time and this process is also identified as a major cause of the biological diversity decline through the time (SMITH; ALI, 2009). Some studies show a decrease in the number of species occurring as a result of the increase of the fragment isolation or due to the reduction of the fragment dimensions (BIERREGAARD et al., 1992; TURNER; 1996; LAURANCE; BIERREGAARD, 1997).

Studies regarding the impact of habitat fragmentation and those that characterize the local vegetation and floristic similarities among the remaining areas in Central Brazil are still scarce (CARVALHO; DE MARCO JUNIOR; FERREIRA, 2009; GARCIA et al., 2011). The southern Goiás studied region is dominated by semideciduous seasonal forests, but their natural landscapes became a fragmented mosaic due to extensive cattle farming and agricultural activities that succeed in those rich basaltic originated soils (VIANA; TABANEZ; BATISTA, 1997; CARVALHO; DE MARCO JUNIOR; FERREIRA, 2009). Currently, only 3\% of the studied region is covered by the forests of the transitional ecotone established between the Atlantic
Forest and the Neotropical Savanna physiognomies. Additionally, the majority of the forest remnants are situated on private properties and they are generally very vulnerable to continuing disturbances principally because of their unsustainable use. Over the past two years, for example, there was a $0.43 \%$ rate of deforestation of the Atlantic Forest in the region (SOS MATA ATLÂNTICA; INPE, 2010).

Accordingly to many researchers, the phytosociological and floristic composition studies of forests, which provide data on the structural organization of their plant species populations, are the basis for developing management strategies of conservation and restoration of their remnants (HARIDASAN; ARAUJO, 2005; PINTO et al., 2007; DURIGAN et al., 2008; SILVA; ARAUJO, 2009).

The purpose of the present study was to determine the floristic composition and abundance of the arboreal ad subarboreal components of four semideciduous forest fragments in southern Goiás, Brazil. We tested the hypotheses that the geographically closer fragments of the studied area would be floristically more similar and that the fragment area would have a direct relationship with its floristic diversity. 


\section{MATERIAL AND METHODS}

\section{Study Area}

Collections were made in four remaining fragments (F1, F2, F3, F4) of Semideciduous Seasonal Forest located in a transitional area between the Savanna and Atlantic Dense Ombrophilous, in the municipality of Itumbiara, Brazil $\left(18^{\circ} 25^{\prime} 12^{\prime \prime} \mathrm{S}\right.$ and $\left.49^{\circ} 13^{\prime} 04^{\prime \prime} \mathrm{W}\right)$, in altitudes between 320 to $448 \mathrm{~m}$ (IBGE, 2012). The region is drained by the rivers Paranaíba, Meia Ponte and dos Bois, in areas covered by eutrophic soil of medium to high fertility originated from basaltic rocks (RESENDE et al., 1997). Rainfall concentration occurs during the warmer months (October to March), interspersed by a 4 to 5 month period of dry months (April to September) when the water deficit is accentuated (NISHIYAMA, 1989; SOS MATA ATLÂNTICA; INPE, 2010).

F1 $\left(18^{\circ} 20^{\prime} 80^{\prime \prime} \mathrm{S}\right.$ and $\left.49^{\circ} 04^{\prime} 77^{\prime \prime} \mathrm{W}\right)$ is the largest fragment with 57 ha $(1.67 \times 0.34 \mathrm{~km})$, covered with a dense and well maintained understory and composed by shrubs and small trees of an average height of $2.5 \mathrm{~m}$. It contains an abundant leaf-litter accumulation throughout the year and the occupation of its surrounding areas changes according to the adopted program of crop rotation.

F2 (18 $20^{\prime} 99^{\prime \prime} \mathrm{S}$ and $\left.49^{\circ} 03^{\prime} 65^{\prime \prime} \mathrm{W}\right)$ has an approximate area of $26 \mathrm{ha}(0.45 \times 0.42 \mathrm{~km})$, and is covered by a sparse understory degraded by fire and timber removal. F2 and F1 have sugarcane cultivation on their surrounding matrix and are both located close to the lake of the Furnas Hydroelectric. In November of 2008, the edges of these two fragments were damaged by fire.

F3 (18 $17^{\prime} 40 " \mathrm{~S}$ and $\left.49^{\circ} 05^{\prime} 56^{\prime \prime} \mathrm{W}\right)$, with 37 ha $(1.08 \times 0.48 \mathrm{~km})$, is characterized by a dense understory, composed by shrubs and small trees of an average height of $3.5 \mathrm{~m}$. The leaf-litter production throughout the year is high and the vegetation, although presenting gaps caused by the fall of large trees, is in good condition. Even though the road that divides part of the fragment has been disabled since 2007, it is common to observe vestiges of bovine cattle activity. It is surrounding by sugarcane cultivation in the eastern and southern edges, soybean cultivation on the western border and pasture on the north edge.

F4 $\left(18^{\circ} 18^{\prime} 70^{\prime \prime} \mathrm{S}\right.$ and $\left.49^{\circ} 05^{\prime} 85^{\prime \prime} \mathrm{W}\right)$, with approximately 22 ha $(0.45 \quad \mathrm{x} \quad 0.30 \mathrm{~km})$ is characterized by a very dense understory, composed by shrubs and small trees of an average height of 2 $\mathrm{m}$. Dense bushes are recovering the areas previous used for wood extraction or those that have been damaged by cattle trampling. It is surrounding by soybean cultivation on the southeast edge, cane sugar in the southwest border and an abandoned pasture on the other edges. Next to this fragment there are other forest remains. The presence of bovine cattle and its vestiges is also observed in this fragment.

The distances between the fragments are as follows: $\mathrm{F} 1-\mathrm{F} 2=0.71 \mathrm{~km}, \mathrm{~F} 1-\mathrm{F} 3=6.01 \mathrm{~km} ; \mathrm{F} 1-\mathrm{F} 4$ $=4.09 \mathrm{~km}, \mathrm{~F} 2-\mathrm{F} 3=6.11 \mathrm{~km}, \mathrm{~F} 2-\mathrm{F} 4=4.19 \mathrm{~km}$ and $\mathrm{F} 3-\mathrm{F} 4=1.42 \mathrm{~km}$.

\section{Method of Collection}

The vegetation diversity was estimated from a survey of the composition and density (considered the floristic abundance) of trees and shrubs in an area of 0.52 ha, located $10 \mathrm{~m}$ from the edges. In each fragment 13 fixed parcels of $20 \times 20 \mathrm{~m}$, disposed in five transects, $10 \mathrm{~m}$ apart from each other, three transects with 3 parcels each and two transects with 2 parcels each. In order to verify the adequacy of the sampling effort species accumulation curves were plotted (SANTOS, 2003). All trees with a circumference of at least $15 \mathrm{~cm}$ at breast height $(1.30 \mathrm{~m})$ were considered in the arboreal stratum sampling. For the sampling of shrubs and small trees of the subarboreal stratum, a subplot of $10 \times 10 \mathrm{~m}$ was established within each parcel, where all individuals $\geq 1 \mathrm{~m}$ height were sampled.

The botanical material was herborized and the identifications were made with the aid of literature, consultations with experts and comparisons with the collections of the Herbarium Uberlandensis. The species nomenclature were recorded according to W3 Tropics (TROPICS, 2010) and grouped into the families recognized by the Angiosperm Phylogeny Group III (CHASE; REVEAL, 2009).

\section{Statistical Analysis}

The Shannon-Wienner index of diversity $\left(\mathrm{H}^{\prime}\right)$ and the Pielou's evenness index (J) were calculated for both strata of each fragment (MAGURRAN, 1989). The diversity indices were compared using Hutcheson $\mathrm{t}$ test, considering a critical value of $2 \%$ error as a form of correction for multiple comparisons (ZAR, 1984). In order to evaluate the sampling effort in terms of species richness of the arboreal and subarboreal strata, the Jackknife 2 species accumulation curves were obtained using the software Estimate $\mathrm{S}$ (COLWELL, 2009).

Floristic similarity was evaluated among the four fragments, employing the Sörensen index 
(BROWER; ZAR 1984), grouped by UPGMA (Unweighted Pair-Group Average Method) using the program FITOPAC 2.1.2 (SHEPHERD, 2011). After employing the Kolmogorov-Smirnov test to confirm the data normal distribution, the Pearson simple correlation was used to verify if the community richness and diversity, the abundance of individuals of both strata and the areas of the fragments are correlated (ZAR, 1984).

The species were categorized as rare, sparse, common and dominant, according to its absolute density in each fragment. The considered interval for determining the amplitude of each category group was calculated by dividing by four the highest value of the absolute density found in each fragment.

The species of the subarboreal stratum were classified as transient or resident. The resident species spend their entire lives in the understory, whereas the transient species remain in the understory while young, reaching adulthood in the canopy (GILLIAM et al. 1994).

Multivariate analyzes were performed using the PC-ORDTM 5 program (MCCUNE; MEFFORD, 2006), in order to explore the similarity of the categorical (presence and absence) and quantitative (absolute density) data. Data were ordered using the Detrended Correspondence
Analysis (DCA) (HILL; GAUCH, 1980) based in a matrix of the absolute density of species in the 52 studied parcels. All analyzes were performed using the statistical program Systat ${ }^{\circledR} 10.2$ (SYSTAT, 2002).

\section{RESULTS}

\section{Floristic Composition and Abundance}

It was recorded 125 species (16 of them identified at the taxonomic level of genus), belonging to 91 genera and 43 botanical families (Table 1). Higher species richness was recorded in the upper stratum (105) than in the subarboreal stratum (76). Fabaceae (23), Myrtaceae (10), Rubiaceae (11), Lauraceae (7) and Vochysiaceae (6) were the families showing the greatest number of species. The Siparunaceae family was represented by a single species Siparuna guianensis Aubl., which was abundant and dominant in both strata of all fragments. Eight species were also present in all fragments and in both vegetative strata, namely: Xylopia aromatica (Lam) Mart., Aspidosperma discolor A. DC., Protium heptaphyllum (Aubl.) Marchand, Cheiloclinium cognatum (Miers) AC $\mathrm{Sm}$, Emmotum nitens (Benth.) Miers, Ocotea corymbosa (Meisn.) Mez., Virola sebifera Aubl. and Siphoneugena densiflora O. Berg.

Table 1. Floristic composition and abundance of the arboreal (Arb) and subarboreal (Sub) strata in four Semideciduous Forest Fragments of Itumbiara, central Brazil. (Absolute number of arboreal species in 0.52 ha area sampled in each fragment and absolute number of shrubs and small trees in 0.13 ha sampled in each fragment).

\begin{tabular}{|c|c|c|c|c|c|c|c|c|}
\hline \multirow{2}{*}{$\begin{array}{l}\text { FAMILY } \\
\text { Species }\end{array}$} & \multicolumn{2}{|c|}{ Fragment 1} & \multicolumn{2}{|c|}{ Fragment 2} & \multicolumn{2}{|c|}{ Fragment 3} & \multicolumn{2}{|c|}{ Fragment 4} \\
\hline & Arb & Sub. & Arb & Sub. & Arb & Sub. & Arb & Sub. \\
\hline \multicolumn{9}{|l|}{ ANACARDIACEAE } \\
\hline Astronium nelson-rosae Santin & 1 & 10 & 3 & 6 & 1 & 0 & 2 & 4 \\
\hline Tapirira guianensis Aubl. & 2 & 0 & 0 & 0 & 4 & 0 & 0 & 0 \\
\hline \multicolumn{9}{|l|}{ ANNONACEAE } \\
\hline Annona montana Macfad. & 0 & 2 & 0 & 0 & 0 & 0 & 0 & 0 \\
\hline Cardiopetalum calophyllum Schltdl. & 3 & 6 & 3 & 1 & 0 & 0 & 1 & 8 \\
\hline Unonopsis guatterioides (A.DC.) R.E.Fr & 0 & 0 & 5 & 0 & 0 & 0 & 0 & 0 \\
\hline Xylopia aromatica (Lam.) Mart. & 16 & 6 & 5 & 4 & 19 & 1 & 16 & 1 \\
\hline \multicolumn{9}{|l|}{ APOCYNACEAE } \\
\hline Aspidosperma cylindrocarpon Müll. & & & & & & & & \\
\hline Arg. & 0 & 0 & 0 & 0 & 2 & 1 & 0 & 1 \\
\hline Aspidosperma discolor A. DC. & 18 & 23 & 42 & 5 & 13 & 13 & 16 & 22 \\
\hline \multicolumn{9}{|l|}{ ARALIACEAE } \\
\hline Schefflera morototoni (Aubl.) Maguire, & & & & & & & & \\
\hline Steyerm. \& Frodin & 40 & 0 & 7 & 0 & 2 & 0 & 14 & 0 \\
\hline \multicolumn{9}{|l|}{ BIGNONIACEAE } \\
\hline Jacaranda cuspidifolia Mart. & 1 & 0 & 0 & 0 & 0 & 0 & 0 & 0 \\
\hline Tabebuia roseoalba (Ridl.) Sandwith & 1 & 2 & 0 & 0 & 0 & 0 & 0 & 0 \\
\hline Tabebuia sp. & 1 & 0 & 0 & 0 & 0 & 0 & 0 & 0 \\
\hline
\end{tabular}




\section{BORAGINACEAE}

Cordia trichotoma (Vell.) Arráb. ex

\section{Steud.}

\section{BURSERACEAE}

Protium heptaphyllum (Aubl.) Marchan

\section{CELASTRACEAE}

Cheiloclinium cognatum (Miers) A.C.

Sm.

CHRYSOBALANACEAE

Hirtella gracilipes (Hook. f.) Prance

Hirtella glandulosa Spreng.

COMBRETACEAE

Terminalia glabrescens Mart.

Terminalia phaeocarpa Eichler

EBENACEAE

Diospyros hispida A. DC.

ELAEOCARPACEAE

Sloanea hirsuta (Schott) Planch ex

\section{Benth}

ERYTHROXYLACEAE

Erythroxylum subracemosum Turcz.

EUPHORBIACEAE

Maprounea guianensis Aubl.

FABACEAE

Albizia sp.

Andira paniculata Benth.

Andira sp.

Apuleia leiocarpa (Vogel) J.F. Macbr.

Bowdichia virgilioides Kunth

Cassia ferruginea (Schrader) Schrader ex DC.

Copaifera langsdorffii Desf.

Dipteryx alata Vogel

Hymenaea courbaril L.

Inga laurina (Sw.) Willd.

Inga sessilis (Vell.) Mart.

Inga sp.

Machaerium acutifolium Vogel

Machaerium brasiliense Vogel

Machaerium villosum Vogel

Ormosia arborea (Vell.) Harms

Plathymenia reticulata Benth.

Platypodium elegans Vogel

Pterodon emarginatus Vogel

Senegalia polyphylla (DC.) Britton \&

Rose

Sweetia fruticosa Spreng.

Tachigali vulgaris L.G.Silva \&

H.C.Lima

Vatairea macrocarpa (Benth.) Ducke ICACINACEAE

Emmotum nitens (Benth.) Miers

\section{LACISTEMATACEAE}

Lacistema aggregatum (P.J. Bergius)

Rusby

\begin{tabular}{|c|c|c|c|c|c|c|}
\hline 1 & 0 & 0 & 0 & 0 & 0 & 0 \\
\hline 20 & 21 & 3 & 4 & 18 & 13 & 25 \\
\hline 24 & 45 & 9 & 1 & 4 & 7 & 10 \\
\hline 52 & 19 & 0 & 0 & 58 & 36 & 15 \\
\hline 4 & 1 & 3 & 0 & 11 & 0 & 0 \\
\hline 11 & 4 & 3 & 0 & 5 & 1 & 6 \\
\hline 0 & 0 & 3 & 0 & 0 & 0 & 0 \\
\hline 0 & 0 & 0 & 0 & 5 & 1 & 0 \\
\hline 0 & 0 & 1 & 0 & 0 & 0 & 0 \\
\hline 1 & 1 & 0 & 2 & 0 & 3 & 0 \\
\hline 12 & 1 & 26 & 2 & 18 & 3 & 15 \\
\hline 0 & 1 & 0 & 0 & 0 & 0 & 0 \\
\hline 0 & 0 & 0 & 0 & 2 & 0 & 0 \\
\hline 15 & 0 & 0 & 0 & 0 & 0 & 0 \\
\hline 2 & 0 & 0 & 0 & 5 & 1 & 3 \\
\hline 0 & 0 & 0 & 0 & 4 & 0 & 0 \\
\hline 0 & 0 & 0 & 0 & 0 & 0 & 1 \\
\hline 1 & 1 & 1 & 0 & 6 & 1 & 2 \\
\hline 2 & 0 & 0 & 0 & 4 & 1 & 1 \\
\hline 1 & 0 & 0 & 0 & 2 & 1 & 1 \\
\hline 2 & 2 & 2 & 2 & 0 & 1 & 5 \\
\hline 0 & 0 & 0 & 1 & 0 & 0 & 1 \\
\hline 1 & 0 & 0 & 0 & 0 & 0 & 0 \\
\hline 0 & 0 & 0 & 0 & 2 & 0 & 0 \\
\hline 0 & 0 & 0 & 0 & 0 & 0 & 1 \\
\hline 0 & 0 & 0 & 0 & 0 & 0 & 1 \\
\hline 3 & 2 & 1 & 0 & 1 & 0 & 2 \\
\hline 2 & 0 & 0 & 0 & 1 & 1 & 1 \\
\hline 1 & 0 & 1 & 0 & 3 & 0 & 0 \\
\hline 0 & 0 & 1 & 0 & 0 & 0 & 0 \\
\hline 4 & 0 & 0 & 0 & 0 & 0 & 0 \\
\hline 0 & 0 & 0 & 0 & 0 & 0 & 1 \\
\hline 2 & 1 & 46 & 3 & 10 & 0 & 4 \\
\hline 0 & 0 & 0 & 0 & 15 & 0 & 0 \\
\hline 33 & 7 & 8 & 2 & 45 & 2 & 18 \\
\hline
\end{tabular}

$\begin{array}{lllllll}0 & 0 & 0 & 0 & 0 & 0 & 0\end{array}$




\section{LAMIACEAE}

Aegiphila integrifolia (Jacq.) Moldenke .

Vitex polygama Cham.

\section{LAURACEAE}

Cryptocarya aschersoniana $\mathrm{Mez}$

Nectandra megapotamica (Spreng.) Mez

Nectandra membranacea (Sw.) Griseb.

Nectandra sp.

Ocotea corymbosa (Meisn.) Mez

Ocotea minarum (Nees \& C. Mart.) Mez

Endlicheria sp.

LOGANIACEAE

Antonia ovata Pohl

MALVACEAE

Guazuma ulmifolia Lam.

Luehea grandiflora Mart.

MELASTOMATACEAE

Miconia affinis DC.

Miconia albicans (Sw.) Triana

Miconia sellowiana Naudin

Miconia tomentosa (Rich.) D. Don ex

DC.

Miconia sp.

MELIACEAE

Cabralea canjerana Saldanha

Guarea guidonia (L.) Sleumer

Trichilia catigua A. Juss.

Trichilia pallida $\mathrm{Sw}$.

\section{MORACEAE}

Pseudolmedia laevigata Trécul

Sorocea bonplandii (Baill.) W.C. Burger,

Lanj. \& Wess. Boer

Ficus sp. 1

Ficus sp. 2

Ficus sp. 3

MYRISTICACEAE

Virola sebifera Aubl.

MYRTACEAE

$\begin{array}{rrrrrrrr}0 & 0 & 1 & 3 & 1 & 0 & 0 & 0 \\ 0 & 0 & 0 & 0 & 1 & 0 & 0 & 0 \\ 0 & 0 & 0 & 0 & 0 & 0 & 1 & 0 \\ 120 & 0 & 0 & 0 & 1 & 0 & 0 & 0 \\ 0 & 44 & 212 & 14 & 2 & 2 & 169 & 15 \\ 0 & 0 & 0 & 0 & 0 & 0 & 9 & 0 \\ 10 & 19 & 8 & 3 & 8 & 10 & 1 & 17 \\ 3 & 0 & 0 & 0 & 0 & 0 & 0 & 0 \\ 0 & 0 & 1 & 0 & 0 & 0 & 0 & 0\end{array}$

Campomanesia velutina (Cambess.) $\mathrm{O}$.

Berg

Eugenia florida DC.

Eugenia sp.

Myrcia splendens (Sw.) DC.

Myrcia tomentosa (Aubl.) DC.

Myrcia variabilis DC.

$\begin{array}{llllllll}13 & 5 & 4 & 0 & 6 & 0 & 2 & 1\end{array}$

$\begin{array}{llllllll}2 & 0 & 0 & 0 & 0 & 0 & 0 & 0\end{array}$

$\begin{array}{llllllll}2 & 0 & 1 & 0 & 1 & 0 & 4 & 1\end{array}$

$\begin{array}{llllllll}1 & 0 & 0 & 0 & 0 & 0 & 0 & 0\end{array}$

$\begin{array}{llllllll}0 & 0 & 0 & 0 & 0 & 14 & 0 & 0\end{array}$

$\begin{array}{llllllll}0 & 0 & 3 & 0 & 0 & 0 & 0 & 0\end{array}$

$\begin{array}{llllllll}0 & 0 & 8 & 1 & 0 & 0 & 0 & 0\end{array}$

$\begin{array}{llllllll}0 & 5 & 0 & 0 & 0 & 0 & 0 & 0\end{array}$

Myrcia tomentosa (Aubl.) DC.

Myrcia sp. 1

Myrcia sp. 2

Psidium sartorianum (O. Berg) Nied.

Siphoneugena densiflora O. Berg

OCHNACEAE

Ouratea castaneifolia (DC.) Engl.

OLACACEAE

Heisteria ovata Benth.

OPILIACEAE

$\begin{array}{rrrrrrrr}3 & 0 & 0 & 0 & 0 & 0 & 0 & 0 \\ 0 & 2 & 0 & 0 & 0 & 0 & 1 & 0 \\ 5 & 0 & 1 & 0 & 0 & 0 & 0 & 0 \\ 1 & 5 & 0 & 0 & 2 & 1 & 0 & 1 \\ 3 & 1 & 3 & 0 & 0 & 0 & 0 & 1 \\ 0 & 1 & 0 & 0 & 0 & 0 & 0 & 0 \\ 3 & 1 & 3 & 0 & 0 & 0 & 0 & 1 \\ 0 & 0 & 0 & 7 & 0 & 0 & 0 & 0 \\ 0 & 0 & 0 & 2 & 0 & 0 & 0 & 0 \\ 0 & 0 & 0 & 0 & 0 & 0 & 1 & 0 \\ 15 & 7 & 41 & 7 & 11 & 3 & 5 & 7 \\ & & & & & & & \\ 0 & 1 & 0 & 0 & 0 & 0 & 0 & 0 \\ & & & & & & & \\ 0 & 0 & 0 & 0 & 1 & 2 & 0 & 0\end{array}$


Agonandra brasiliensis Miers ex Benth.

$\&$ Hook. F.

PHYLLANTHACEAE

Margaritaria nobilis L. f.

PERACEAE

Pera glabrata (Schott) Poepp. ex Baill.

PIPERACEAE

Piper arboreum Aubl.

POLYGONACEAE

Coccoloba mollis Casar.

PROTEACEAE

Roupala montana Aubl.

ROSACEAE

Licania apetala (E. Mey.) Fritsch

Licania kunthiana Hook. F.

RUBIACEAE

Alibertia edulis (Rich.) A. Rich. ex DC.

Amaioua intermedia Mart.

Cordiera sessilis (Vell.) Kuntze

Coussarea hydrangeifolia (Benth.) Müll.

Arg.

Ixora brevifolia Benth

Psychotria prunifolia Kunth

Psychotria sp. 1

Psychotria sp. 2

Psychotria sp. 3

Rudgea viburnoides (Cham.) Benth.

Simira rubra (Mart.) Steyerm

SALICACEAE

Casearia gossypiosperma Briq.

Casearia sylvestris Sw.

$\begin{array}{rrrrrrrr}2 & 0 & 0 & 0 & 0 & 0 & 1 & 0 \\ 0 & 2 & 0 & 0 & 1 & 0 & 2 & 0 \\ 2 & 0 & 1 & 0 & 23 & 0 & 1 & 0 \\ 0 & 1 & 0 & 0 & 0 & 0 & 1 & 4 \\ 1 & 0 & 0 & 0 & 1 & 0 & 1 & 0 \\ 2 & 1 & 0 & 0 & 4 & 0 & 0 & 0 \\ 8 & 5 & 24 & 6 & 0 & 0 & 1 & 2 \\ 0 & 3 & 0 & 0 & 0 & 0 & 0 & 0 \\ & & & & & & & \\ 1 & 0 & 0 & 0 & 1 & 4 & 0 & 0 \\ 0 & 0 & 0 & 0 & 2 & 0 & 0 & 0 \\ 2 & 11 & 2 & 4 & 0 & 12 & 0 & 4\end{array}$

SAPINDACEAE

Cupania vernalis Cambess.

Dilodendron bipinnatum Radlk.

Matayba guianensis Aubl.

SAPOTACEAE

Chrysophyllum marginatum (Hook. \&

Arn.) Radlk.

Micropholis venulosa (Mart. \& Eichler)

Pierre

Pouteria gardneri (Mart. \& Miq.)

Baehni

Pouteria torta (Mart.) Radlk.

SIPARUNACEAE

Siparuna guianensis Aubl.

STYRACACEAE

Styrax camporum Pohl

Styrax pohlii A. DC.

SYMPLOCACEAE

Symplocos nitens (Pohl) Benth.

ULMACEAE

Celtis iguanaea (Jacq.) Sarg.

VOCHYSIACEAE

Callisthene major Mart.

Qualea dichotoma (Mart.) Warm.

$\begin{array}{rrrrrrrr}0 & 0 & 0 & 0 & 0 & 0 & 0 & 1 \\ 6 & 9 & 12 & 0 & 4 & 0 & 0 & 2 \\ 2 & 3 & 0 & 0 & 3 & 0 & 0 & 2 \\ 0 & 0 & 0 & 0 & 0 & 0 & 1 & 0 \\ 47 & 62 & 83 & 48 & 83 & 107 & 102 & 108 \\ 1 & 1 & 0 & 0 & 0 & 1 & 0 & 0 \\ 0 & 0 & 5 & 0 & 0 & 0 & 0 & 0 \\ 0 & 1 & 0 & 0 & 0 & 0 & 0 & 0 \\ 0 & 1 & 0 & 0 & 0 & 0 & 0 & 0 \\ 12 & 0 & 8 & 0 & 1 & 0 & 1 & 0 \\ 2 & 0 & 1 & 0 & 0 & 0 & 0 & 0\end{array}$


Floristic composition...

SOARES, N. S. et al.

Qualea grandiflora Mart.

Qualea multiflora Mart.

Vochysia haenkeana Mart.

Vochysia tucanorum Mart.

The species accumulation curves (Figure 1) confirmed that the collection effort was adequate, since they reached a stable number of species in spite of the addition of sample parcels. Among the 105 species sampled in the arboreal stratum, 61 were not found in the subarboreal stratum as Schefflera morototoni (Aubl.) Maguire, Pera glabrata (Schott) Poepp. ex Baill. and Callisthene major Mart., all of which were present in the four fragments. In contrast, 21 species were exclusive of

the subarboreal stratum as for example, Sorocea bonplandii (Baill) WC Burger. Lanj. \& Wess. Boer and Cupania vernalis Cambess, both encountered in the four fragments and Psychotria prunifolia Kunth present in three fragments (F1, F3, F4) in abundance of specimens (8, 85 and 15 respectively). It also highlights the abundant presence of the shrubs Psychotria spp. and Erythroxylum subracemosum Turcz.
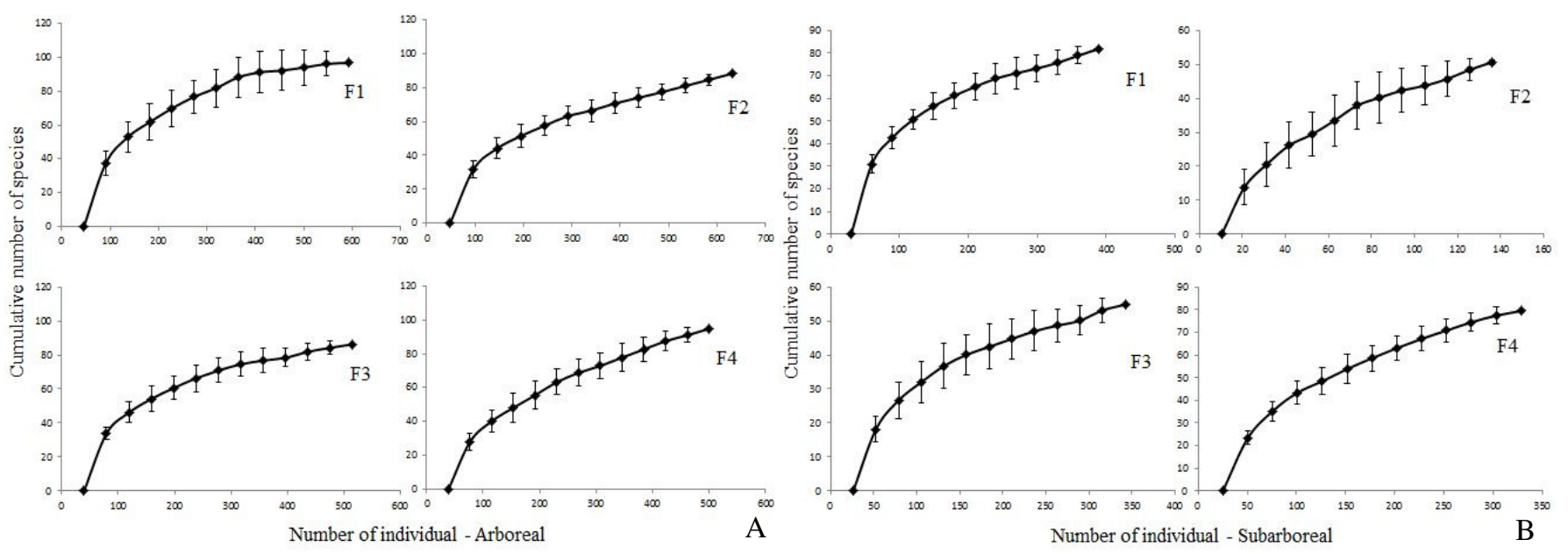

Figure 1. Jackknife 2 species estimator curves in four semideciduous forest fragments in Itumbiara, GO, Brazil. A - arboreal stratum; B - subarboreal stratum

Most species did not occur simultaneously in all fragments, with 21 of them being exclusive of F1 (11 in the arboreal, 9 in the subarboreal and 1 in both strata), 13 in F2 (10 in the arboreal, 2 in the subarboreal and 1 in both strata), 7 in F3 (5 in the arboreal, 1 in the subarboreal and 1 in both strata) and 14 in F4 (10 in the arboreal, 3 in the subarboreal and 1 in both strata). In F1, the most abundant exclusive species were Andira sp. and Miconia sp., while in F2, Unonopsis guatterioides (A.DC.) R.E.Fr., Styrax pohlii A. DC. and Myrcia sp.1 were the most frequent. In the same way, Bowdichia virgilioides Kunth, Miconia albicans (Sw.) Triana were the most abundant exclusive species in F3, while in F4, Nectandra sp. and Trichilia catigua A. Juss. were the most frequent.

Most of the species of both vegetative strata were considered rare, representing less than $25 \%$ of the highest absolute density founded for each fragment (Table 2). However, all fragments showed a single dominant species, except the subarboreal stratum of F3. Nectandra membranacea (Sw.) Griseb. was dominant in F2 and F4 in the upper stratum, representing about $33 \%$ of sampled individuals, but it was rare in F1 and F3. Nectandra megapotamica (Spreng.) Mez was dominant in F1 (20.2\%) but, in contrast, it was rare in the other fragments. S. guianensis was dominant in F3 $(16.1 \%)$ and sparse in F1, F2 and F4.

The subarboreal strata of all fragments were dominated by $S$. guianensis, although $P$. prunifolia had been co-dominant in F3. Cheiloclinium cognatum (Miers) $\mathrm{AC} \mathrm{Sm}$ and N. membranacea were frequent in F1, but these species were sparse in F2 and F4. 
Table 2. Degree of dominance (given in terms of number of species) in the four semideciduous forest fragmentos of Itumbiara, central Brazil. The categorization were done considering ranges for the abundance percentages values of each species in relation to the greater abundance found in each fragment per vegetative stratum).

\begin{tabular}{|c|c|c|c|c|c|c|c|c|}
\hline \multirow{2}{*}{$\begin{array}{l}\text { Categories (number of } \\
\text { individuals per especies) }\end{array}$} & \multicolumn{4}{|c|}{ Arboreal } & \multicolumn{4}{|c|}{ Subarboreal } \\
\hline & F 1 & F 2 & F 3 & F 4 & F1 & F 2 & F3 & F 4 \\
\hline Dominant $(>75 \%)$ & 1 & 1 & 1 & 1 & 1 & 1 & 2 & 1 \\
\hline Common $(>50 \%$ e $<75 \%)$ & - & - & 3 & 2 & 2 & - & - & - \\
\hline Sparse $(>25 \%$ e $<50 \%)$ & 5 & 1 & 2 & - & 4 & 1 & 1 & 1 \\
\hline Rare $(<25 \%)$ & 56 & 48 & 47 & 53 & 45 & 27 & 31 & 43 \\
\hline
\end{tabular}

Most of the species sampled in the subarboreal stratum were classified as transient and only ten species were fitted in the resident component, as follows: Aegiphila integrifolia (Jacq.) Moldenke, Celtis iguanea (Jacq.) Sarg., Coussarea hydrangeifolia (Benth.) Müll., Miconia albicans, Psychotria prunifolia, Psychotria sp. 1, Psychotria sp. 2 , Psychotria sp. 3, Rudgea viburnoides (Cham.) Benth. e Siparuna guianensis.

\section{Fragments' Diversity and Similarity}

The diversity indexes estimated for the arboreal stratum of the largest fragments (F1 and
F3) were significantly higher than those of the others. The diversity index of the subarboreal strata was higher in the largest fragment (F1), followed by F2 and F4, the two smallest fragments, whose indexes do not differ significantly. Low values of evenness were obtained on both vegetative strata in all fragments, varying from 0.4 to 0.5 (Table 3 ).

Only the species richness of the arboreal stratum was significantly correlated with the fragment area (Table 4).

Table 3. Area of the fragments and plant community characteristics of four semideciduous forest fragments in Itumbiara, central Brazil. (Arb: arboreal, Sub: subarboreal). Different letters in the same column of the table designate significant differences in the Hutcheson t test for $\mathrm{H}^{\prime}$ fragment pair comparisons, considering critical value of $2 \%$ error).

\begin{tabular}{|c|c|c|c|c|c|c|c|c|c|}
\hline \multirow[t]{2}{*}{ Fragments } & \multirow[t]{2}{*}{$\begin{array}{l}\text { Area } \\
\text { (ha) }\end{array}$} & \multicolumn{2}{|c|}{$\begin{array}{l}\text { Shannon } \\
\text { index (H') }\end{array}$} & \multicolumn{2}{|c|}{$\begin{array}{l}\text { Pielou index } \\
\text { (J) }\end{array}$} & \multicolumn{2}{|c|}{ Richness } & \multicolumn{2}{|c|}{ Abundance } \\
\hline & & Arb. & Sub. & Arb. & Sub. & Arb. & Sub. & Arb. & Sub. \\
\hline Fragr & 57 & $3.20 \mathrm{a}$ & $3.12 \mathrm{a}$ & 0.501 & 0.5 & 62 & 52 & 592 & 389 \\
\hline FragI & 26 & $2.84 \mathrm{~b}$ & $2.46 \mathrm{~b}$ & 0.440 & 0.522 & 50 & 29 & 631 & 136 \\
\hline Fragme & 34 & $3.13 \mathrm{a}$ & $2.42 \mathrm{c}$ & 0.502 & 0.416 & 53 & 3 & 514 & 342 \\
\hline Fragment 4 & 22 & $2.76 \mathrm{~b}$ & $2.77 b$ & 0.444 & 0.479 & 55 & 45 & 501 & 324 \\
\hline
\end{tabular}

Table 4. Pearson's correlation between the fragment area and the community diversity and richness and the abundance of specimens of both arboreal and subarboreal strata (Significant value in bold).

\begin{tabular}{lccccc}
\hline & \multicolumn{2}{c}{ Arboreal } & & \multicolumn{2}{c}{ Subarboreal } \\
\cline { 2 - 3 } \cline { 6 - 7 } & $\mathrm{r}$ & $\mathrm{P}$ & & $\mathrm{R}$ & $\mathrm{p}$ \\
\hline Diversity x area & 0.870 & 0.130 & & 0.697 & 0.303 \\
Richness x area & 0.969 & $\mathbf{0 . 0 3 0}$ & & 0.621 & 0.379 \\
Abundance x area & 0.300 & 0.700 & & 0.589 & 0.411 \\
\hline
\end{tabular}

The Sörensen floristic similarity analysis generally indicated low similarity between the fragments for both evaluated strata. For the arboreal stratum the analysis indicated greatest similarity between F1 and F3 (approximately 46\%), both keeping a similarity of about $30 \%$ with $\mathrm{F} 4$.

The similarity grouping analysis for the subarboreal stratum was distinct from the arboreal stratum, F1 and F4 showing an approximately 56\% of similarity and both keeping about $35 \%$ of similarity with F3. F2 showed $25 \%$ of similarity with the others. The resulting ordination diagram of the parcels revealed by DCA (Figure 2) corroborates the Sörensen similarity pattern described between the fragments for the arboreal stratum. The first axis of the DCA ordination explains $48.47 \%$ of the variation and separates $\mathrm{F} 1$ and $\mathrm{F} 3$ from $\mathrm{F} 2$ and and F4. The first two axes together explain $76.56 \%$ and 
the diagram generated by the first two axes clearly separates the analyzed parcels and fragments.

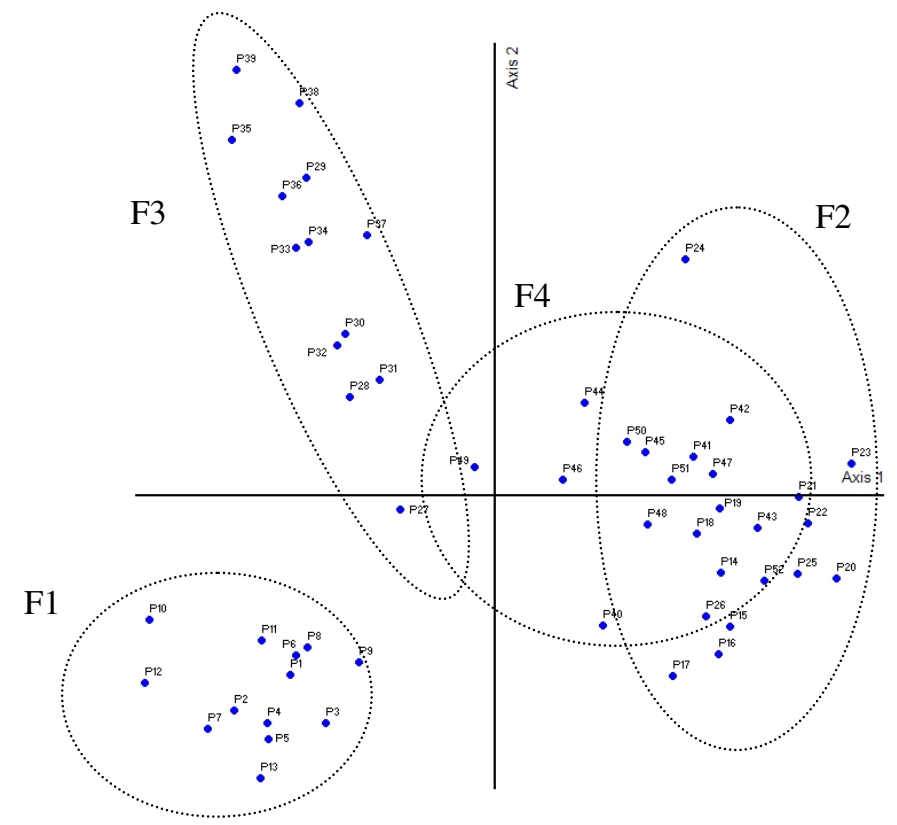

Figure 2. Ordination of 52 parcels sampled in the arboreal stratum of the four (F1 to F4) semideciduous forest fragments in Itumbiara, central Brazil, considering the first (horizontal) and second (vertical) axis of a Detrended Correspondence Analysis (DCA).

In relation to the subarboreal stratum, the resulting ordination diagram (Figure 3) shows the confluence between the fragments accordingly the grouped parcels at the axis center. The first axis explains only $38.50 \%$ of the variation and the second axis, $2.41 \%$, which means that there is not a markedly difference between the studied parcels.

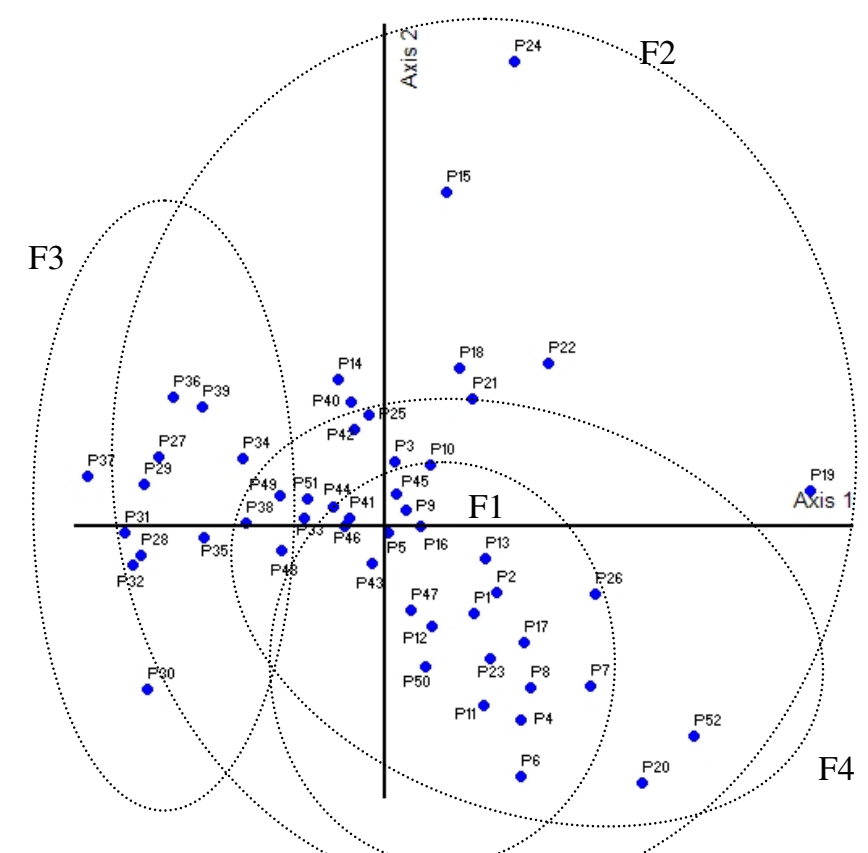

Figure 3. Ordination of 52 parcels sampled in the subarboreal stratum of four (F1 to $F 4$ ) semideciduous forest fragments in Itumbiara, central Brazil, considering the first (horizontal) and second (vertical) axis of a Detrended Correspondence Analysis (DCA). 


\section{DISCUSSION}

\section{Flora Abundance}

The forest fragments have common characteristics, such as the occurrence $S$. guianensis, $X$. aromatica, $A$. discolor, $P$. heptaphyllum $C$. cognatum, E. nitens, O. corymbosa, V. sebiferae and $S$. densiflora in the two studied strata. However, they differ in most of their floristic composition, since several unique species and distinct patterns of abundance and dominance of species were found in each fragment.

The abundant occurrence of $S$. guianensis in all fragments is probably related to its wide ecological tolerance. This species had been record in very distinct situations such as at climax in shadow conditions, among the pioneer groups of plant species, within or in the edges of some fragments (NUNES et al., 2003; PINTO et al., 2005; CARVALHO; NASCIMENTO; BRAGA, 2007) or in primary and secondary forests with elevations up to $1,200 \mathrm{~m}$ (SOUZA et al., 2006). Moreover, it has a wide geographical distribution in South America, occurring from Nicaragua to Paraguay (REUNNER; HASNER, 2005).

The domain of $S$. guianensis in one tropical lowland rain forest fragment in the central-north region of Rio de Janeiro reported by Carvalho and collaborators (2007), points out its importance as a regenerative species of the secondary forest understories. This species was also recorded in other semideciduous forests at medium/high degree of conservation in the Triângulo Mineiro, Brazil (PRADO JUNIOR et al., 2010; LOPES et al., 2012).

On the other hand, $S$ guianensis has not been always dominant in the arboreal stratum as occurred in F1, F2 and F4, where two Nectandra species were found in high numbers, even not being dominant in the subarboreal stratum. Reitz and collaborators (1983) have already registered the strong regenerative ability of Nectandra spp. in comparison to other rain forests tree species. Nectandra megapotamica and $N$. membranacea were previously recorded in other semideciduous forests of the Triângulo Mineiro region (DIAS NETO et al., 2009; LOPES et al., 2012) showing low densities. Besides, N. megapotamica presented high importance values in a semideciduous forest located in southern Goiás (MILHOMEM; ARAÚJO; VALE, 2013). These findings corroborate the importance of the forest fragments to the maintenance of these species in the region, particularly by providing seeds that can be dispersed to neighboring areas.
It is supposed that seed predation, seedlings herbivory or the action of abiotic factors such as availability of light and destructive effects of fire could explain why about 53\% of inventoried tree species were not sampled in the subarboreal stratum (GUREVITCH; SCHEINER; FOX, 2009). Scariot (2000) verified in some fragments that the damage to the seedlings tend to be more severe if associated to edge effects, as seen in F3 and F4 due to bovine cattle foraging. In contrast, $27 \%$ of the species sampled in the subarboreal stratum were not collected in the arboreal stratum. Probably, these species are resident herbaceous and shrub plants, which show little variation in height throughout their life story, therefore not transposing their original vertical stratification group (GILLIAM et al., 1994).

It should be emphasized that some species such as $P$. prunifolia, abundantly found in all fragments, do not reach a tree stature. Delprete (2001) reports the trend toward consolidation of this shrub species in shaded portions of the environment that have moist soils with high concentrations of aluminum.

The species encountered in all fragments were not always abundant as, for example, $S$. bonplandii and $C$. vernalis, classified as rare. In addition, the unique species of each fragment also occurred in low numbers. In spite of the relatively small size of the sampled fragments, these facts point to the risk of rapid decline or local extinction of many plant species populations of the remaining semideciduous forests of Itumbiara in response to their increasing fragmentation (GARCIA et al., 2011).

\section{Floristic Similarity}

Despite the low similarity among fragments, which were less than $50 \%$, the analysis did not confirm the prediction that nearest fragments would have greater floristic similarity.

Geographic proximity influencing the greatest similarity between fragments has been, however, illustrated by Durigan and collaborators (2008) in fragment plant communities in the Atlantic plateau of São Paulo region. Nevertheless, Santos and collaborators (2007) showed that preexisting environmental heterogeneity may also play an important role generating variability in the floristic composition of close fragments.

The confluence pattern of aggregation of the subarboreal stratum from the sampled parcels revealed by DCA analysis possibly indicates the occurrence of common resident and transient species in all fragments (GALEANO; SUÀREZ; 
BALSLEV, 1998). Nevertheless, this original resemblance tended to decrease through time, as seen in the DCA analysis of the arboreal stratum, probably due to the peculiar internal environmental characteristics of each fragment or as a result of their surroundings disturbing influences (HOST; PREGITZER, 1992; GILLIAM; TURRILL; ADAMS, 1995).

Tabarelli and Mantovani (1999) found in a semidecidual forest fragment in São Paulo a $15.5 \%$ reduction in the basal area 40 years after the occurrence of clearcutting and fire in the fragment. Similarly, it is believed that the low abundance and richness of the subarboreal stratum of F2 may have been the result of intense human activity or a consequence of the action of fire in this fragment, which occurred about 3 months before sampling. Toniato and Oliveira-Filho (2004) also found lower diversity in fragments with intense bovine cattle trampling activity.

Although all the fragments were delimited by sugarcane cultivation, the action of fire and the presence of other crops surrounding the fragments do not allow the evaluation of the environment influence in their floristic composition. However, as little similarity was found between fragments, having the same type of surroundings, it is believed that their influence is not significant for the studied plant community configuration.

\section{Floristic Diversity and Size of the Fragments}

The significant correlation between the arboreal species richness and the fragment dimensions and the tendency of the diversity to increase in larger fragments confirmed the initial hypothesis that the fragment size is influencing the floristic composition.

Mazerolle and Villard (1999) demonstrated significant effects of the fragment boundary shape and characteristics of the surrounding landscape influencing directly their species composition. Besides, many studies confirmed that the fragment size has a strong effect on their edge and interior species configuration (SAUNDERS, HOBBS; MARGULES, 1991; HAILA, 2002; TURNER, 2005).

Cabacinha and Castro (2009) had already observed that the shape and size of the area occupied by the vegetation could influence their floristic diversity in forest fragments of the Savanna. However, these authors argue that the richness and abundance of species also appear to be related to the connectivity or to the degree of isolation of forest fragments. Thus, smaller fragments tend to have low diversity when completely isolated. On the other hand, small fragments would have greater diversity when interconnected and embedded in a matrix that favors natural population gene flow.

Poggiani and Oliveira (1997) understand that larger and regular shaped fragments also have larger internal area and are better protected from edge effects and argue that the proximity of the edges to the central area can be detrimental to the conservation of species not adapted to anthropogenic effects.

Cushman and collaborators (2012) recently observed significant correlation between genetic distance and cost distance in landscapes with high fragmentation compared to those with low fragmentation. In addition, Rybicki and Hanski (2013) declared that an effective way to combat the fragmentation effect is to aggregate habitat fragments into clusters rather than to place them randomly across the landscape.

\section{CONCLUSIONS}

The data presented indicates that the floristic richness of the semidecidual forest fragments of Itumbiara is influenced by their size, since larger fragments have greater diversity than smaller ones. However, the proximity among fragments does not promote greater similarity on the floristic composition of these fragments.

As even the smaller fragments have unique species and most species had rare occurrence, it emphasizes the importance to preserve these areas and the need of a management and connectivity plan to promote the restoration or the increase in gene flow among the fragments.

As the region is destined to agricultural activities, the expansion of cultivation or livestock areas should be carefully planned to avoid the risk of extinction or biodiversity loss.

RESUMO: A fragmentação das florestas tropicais tem sido apontada como a principal causa da redução de sua biodiversidade. Este processo está ocorrendo intensamente no sul de Goiás, onde ainda são escassas as informações sobre flora e fauna remanescentes. Este estudo objetivou determinar a composição florística e a abundância dos componentes arbóreos e arbustivos de quatro fragmentos de Floresta Estacional Semidecidual. Os dados obtidos indicam que a similaridade e a diversidade florística dos fragmentos são influenciadas pelo seu tamanho, uma vez que fragmentos 
maiores possuem maior diversidade. Entretanto, a proximidade dos fragmentos não se relaciona com sua composição florística. Ao todo, registraram-se 126 espécies pertencentes a 91 gêneros distribuídos em 43 famílias, com dominância de Siparuna guianensis em todos os fragmentos. Mais da metade das espécies encontradas no estrato arbóreo não foram registradas no estrato subarbóreo, havendo também espécies exclusivas desse estrato. Em cada fragmento foi registrado um alto número de espécies exclusivas, o que demonstra a importância da conservação desses remanescentes, independente do seu tamanho e a necessidade de criação de um plano manejo de conectividade entre as áreas.

PALAVRAS-CHAVE: Diversidade. Cerrado. Mata Atlântica. Similaridade.

\section{REFERENCES}

BIERREGAARD, R. O.; LOVEJOY, T. E.; KAPOS, V.; SANTOS, A. A.; HUTCHINGS, R. W. The biological dynamics of tropical rainforest fragments. A prospective comparison of fragments and continuous forest. BioScience, Berkeley, v. 4, n. 11, p. 859-866, 1992. http://dx.doi.org/10.2307/1312085

BROWER, J. E.; ZAR, J. H. Field and laboratory methods for general ecology. Dubuque: W. M. C. Brow, 1984. $226 \mathrm{p}$.

CABACINHA, C. D.; CASTRO, S. S. Relationships between floristic diversity and vegetation indices, forest structure and landscape metrics of fragments in Brazilian Cerrado. Forest Ecology and Management, Netherlands, v. 257, n. 10, p. 2157-2165, 2009. http://dx.doi.org/10.1016/j.foreco.2009.02.030

CARVALHO, F. A.; NASCIMENTO, M. T.; BRAGA, J. M. A. Estrutura e composição florística do estrato arbóreo de um remanescente de Mata Atlântica sub-montana no município de Rio Bonito, RJ, Brasil (mata rio Vermelho). Revista Árvore, Viçosa, v. 31, n. 4, p. 717-730, 2007. http://dx.doi.org/10.1590/S010067622007000400017

CARVALHO, F.; DE MARCO JÚNIOR, P.; FERREIRA, L. The Cerrado into pieces: habitat fragmentation as a function of landscape use in the savannas of central Brazil. Biological Conservation, Philadelphia, v. 142, n. 7, p. 1392-1403, 2009. http://dx.doi.org/10.1016/j.biocon.2009.01.031

CHASE, M. W.; REVEAL, J. L. A phylogenetic classification of the land plants to accompany APG III. Botanical Journal of the Linnean Society, London, v. 161, n. 2, p. 122-127, 2009.

http://dx.doi.org/10.1111/j.1095-8339.2009.01002.x

COLWELL, R. K. Estimate S 8.2. User's Guide. Storrs, Department of Ecology \& Evolutionary Biology, University of Connecticut, 2009.

CUSHMAN, S. A.; SHIRK, A.; LANDGUTH, E. L. Separating the effects of habitat area, fragmentation and matrix resistance on genetic differentiation in complex landscapes. Landscape Ecology, Oxford, v. 27, p. 369380, 2012. http://dx.doi.org/10.1007/s10980-011-9693-0

DIAS NETO, O. C.; SCHIAVINI, I.; LOPES, S. F.; VALE, V. S.; GUSSON, A. E.; OLIVEIRA, A. P. Estrutura fitossociológica e grupos ecológicos em fragmento de floresta estacional semidecidual, Uberaba, Minas Gerais, Brasil. Rodriguésia, Rio de Janeiro, v. 60, n. 4, p. 1087-1100, 2009.

DELPRETE, P. G. Notes on some South American species of Psychotria subgenus Heteropsychotria (Rubiaceae), with observations on rubiaceous taxonomic characters. Brittonia, Bronx, v. 53, n. 3, p. 96-404, 2001. http://dx.doi.org/10.1007/BF02809794

DURIGAN, G.; BERNACCI, L. C.; FRANCO, G. A. D. C. F.; ARBOCZ, G. F.; METZGER, J. P.; CATHARINO, E.L.M. Estádio sucessional e fatores geográficos como determinantes da similaridade florística entre comunidades florestais no Planalto Attântico, Estado de São Paulo, Brasil. Acta Botanica Brasilica, Belo Horizonte, v. 22, n. 1, p. 51-62, 2008. http://dx.doi.org/10.1590/S0102-33062008000100007 
GALEANO, G., S. SUÁREZ; H. BALSLEV. Vascular plant species count in a wet forest in the Chocó area on the Pacific Coast of Colombia. Biodiversity and Conservation, Netherlands, v. 7, p. 1563-1575, 1998. http://dx.doi.org/10.1023/A:1008802624275

GARCIA, P. O.; VALENTE, A. S. M.; PIFANO, D. S.; PESSOA, J. F. S.; BUSATO, L. C.; FONTES, M. A. L.; OLIVEIRA-FILHO, A. T. Species composition and floristic relationships in Southern Goiás forest enclaves. Rodriguésia, Rio de Janeiro, v. 62, n. 1, p. 123-137, 2011.

GILLIAM, F. S.; TURRILL, N. L.; AULICK, S. D.; EVANS, D. K.; ADAMS, M. B. Herbaceous layer and soil response experimental acidification in a central Appalachian hardwood forest. Journal of Environmental Quality, Cambridge, v. 23, p. 835-844, 1994. http://dx.doi.org/10.2134/jeq1994.234835x

GILLIAM, F. S., N. L TURRIL; M. B. ADAMS. Herbaceous-layer and overstory species in clear-cut and mature central Appalachian hardwood forests. Ecological Applications, New York, v. 5, p. 947-955, 1995. http://dx.doi.org/10.2307/2269345

GUREVITCH, J.; SCHEINER, S. M.; FOX, G. A. Ecologia Vegetal. Porto Alegre: Artmed, 2009. 592 p.

HAILA, Y. A conceptual genealogy of fragmentation research: from island. biogeography to landscape ecology. Ecological Applications, New York, v. 12, n.2, p. 321-340, 2002. http://dx.doi.org/10.2307/3060944

HARIDASAN, M.; ARAÚJO, G. M. 2005. Perfil nutricional de espécies lenhosas de duas florestas semidecíduas em Uberlândia, MG. Revista Brasileira de Botânica, São Paulo, v. 28, n. 2, p. 295-303, 2005. http://dx.doi.org/10.1590/S0100-84042005000200010

HILL, M. O.; GAUCH, H. G. Detrended correspondence analysis: an improved ordination technique. Vegetatio, New York, v. 42, n. 1, p. 47-58, 1980. http://dx.doi.org/10.1007/BF00048870

HOST, G. E; PREGITZER, K. S. Geomorphic influences on ground-flora and overstory composition in upland forests of northwestern lower Michigan. Canadian Journal of Forest Research, Ottawa, v. 22, p. 1547-1555, 1992. http://dx.doi.org/10.1139/x92-205

IBGE - Instituto Brasileiro de Geografia e Estatística. Manual Técnico da Vegetação Brasileira. Manuais Técnicos em Geociências. Rio de Janeiro: IBGE, 2012.

LAURANCE, W. F.; BIERRERGAARD, R. O. Tropical forest remnants - ecology, management and conservation of fragmented communities. Chicago: University of Chicago Press, 1997. 616 p.

LOPES, S. F.; SCHIVAVINI, I.; OLIVEIRA, A. P.; VALE, V. S. An ecological comparison of floristic composition in seasonal semideciduous forest in southeast Brazil: implications for conservation. International Journal of Forestry Research, New York, v. 2012, p. 1-14, 2012. http://dx.doi.org/10.1155/2012/537269

MAGURRAN, A. E. Diversidad ecológica y su medición. Barcelona: Ediciones Vedrá, 1989. 200 p.

MAZEROLLE, M. J.; VILLARD, M. A. Patch characteristics and landscape context as predictors of species presence or abundance: a review. Ecoscience, Washington, v. 6, p. 117-124, 1999.

MCCUNE, B.; MEFFORD, M. J. PC-ORD. Multivariate analysis of ecology data. version 5. MjM Software, Oregon: Gleneden Beach, 2006.

MILHOMEM, M. E. V.; ARAÚJO, G. M.; VALE, V. S. Estrutura do estrato arbóreo e regenerativo de um fragmento de floresta estacional semidecidual em Itumbiara,GO. Ciência Florestal, Santa Maria, v. 23, n. 4, p. 679-690, 2013. http://dx.doi.org/10.5902/1980509812352 
NISHIYAMA, L. Geologia do município de Uberlândia e áreas adjacentes. Sociedade \& Natureza, Uberlândia, n. 1, v. 1, p. 9-16, 1989.

NUNES, Y. R. F.; MENDONÇA, A. V. R.; BOTEZELLI, L.; MACHADO, E. L. M.; OLIVEIRA-FILHO, A. T. Variações da fisionomia, diversidade e composição de guildas da comunidade arbórea em um fragmento de floresta semidecidual em Lavras, MG. Acta Botanica Brasilica, Belo Horizonte, v. 17, n. 2, p. 213-229, 2003. http://dx.doi.org/10.1590/S0102-33062003000200005

PINTO, L. V. A.; BOTELHO, S. A.; OLIVEIRA-FILHO, A. T.; DAVIDE, A. C. Estudo da vegetação como subsídios para propostas de recuperação das nascentes da bacia hidrográfica do Ribeirão Santa Cruz, Lavras, MG. Revista Árvore, Viçosa, v. 29, n. 5, p. 775-793, 2005. http://dx.doi.org/10.1590/S010067622005000500013

PINTO, S. I. C.; MARTINS, S. V.; SILVA, A. G.; BARROS, N. F.; DIAS, H. C. T.; SCOSS, L. M. Estrutura do componente arbustivo-arbóreo de dois estádios sucessionais de floresta estacional semidecidual na reserva florestal mata do Paraíso, Viçosa, MG, Brasil. Revista Árvore, Viçosa, v. 31, n. 5, p. 823-833, 2007. http://dx.doi.org/10.1590/S0100-67622007000500006

POGGIANI, F. E; OLIVEIRA, R. E. Indicadores para conservação dos núcleos de vida silvestre. Serie técnica IPEF, Piracicaba, v. 12, n. 31, p. 45-52, 1997.

PRADO JÚNIOR, J. A.; VALE, V. S.; OLIVEIRA, A. P.; GUSSON, A. E.; DIAS NETO, O. C.; LOPES, S. F.; SCHIVAVINI, I. Estrutura da comunidade arbórea em um fragmento de Floresta Estacional Semidecidual localizada na reserva legal da fazenda Irara, Uberlândia, MG. Bioscience Journal, Uberlândia, v. 26, n. 4, p. 683-647, 2010.

REITZ, R; KLEIN, R. M.; REIS, A. Projeto madeira do Rio Grande do Sul. Porto Alegre: Secretaria da Agricultura e de Abastecimento, 1983. 808 p.

RENNER, S. S.; HAUSNER, G. 2005. Monograph of Siparunaceae. Flora Neotropica 95. New York: New York Botanical Garden, 2005. 256 p.

RESENDE, M.; CURI, N., REZENDE, S. B.; CORREA, G. F. 1997. Pedologia: base para distinção de ambientes. Viçosa: NEPUT, 1987. 367 p.

RYBICKI, J.; HANSKI, I. Species-area relationships and extinctions caused by habitat loss and fragmentation. Ecology Letters, Singapore, v. 16, p. 27-38, 2013. http://dx.doi.org/10.1111/ele.12065

SANTOS, A. J. Estimativas de riqueza em espécies. In: CULLEN JR.L.;VALLADARES-PÁDUA, C.; RUDRAN, R.(Ed). Métodos de estudos em biologia da conservação e manejo da vida silvestre. Curitiba: Fundação O Boticário de Proteção à Natureza, 2003. p. 19-41. http://dx.doi.org/10.1016/j.biocon.2006.10.027

SANTOS, K.; KINOSHITA, L. S.; SANTOS, F. A. M. Tree species composition and similarity in semideciduous forest fragments of southeastern Brazil. Biological Conservation, Philadelphia, v. 135, n. 2, p. 268-277, 2007. http://dx.doi.org/10.1111/j.1523-1739.1991.tb00384.x

SAUNDERS, D.; HOBBS, R. J.; MARGULES, C. R. Biological consequences of ecosystem fragmentation: a review. Conservation Biology, Philadelphia, v. 5, p. 18-32, 1991. http://dx.doi.org/10.1111/j.15231739.1991.tb00384.x

SCARIOT, A. Seedling mortality by litterfall in Amazonian forest fragments. Biotropica, Malden, v. 32, n. 4 , p. 662-669, 2000. http://dx.doi.org/10.1646/0006-3606(2000)032[0662:SMBLIA]2.0.CO;2

SHEPHERD, G. J. Fitopac 2.1.2 - Manual do usuário. Campinas: Unicamp, 2011. 90 p. 
SILVA, M. R.; ARAUJO, G. M. 2009. Dinâmica da comunidade arbórea de uma floresta semidecidual em Uberlândia, MG, Brasil. Acta Botanica Brasilica, Belo Horizonte, v. 23, n. 1, p. 49-56, 2009. http://dx.doi.org/10.1590/S0102-33062009000100006

SOUZA, P. A.; VENTURIN, N.; GRIFFITH, J. J.; MARTINS, S. V. Avaliação do banco de sementes contido na serapilheira de um fragmento florestal visando recuperação de áreas degradadas. Revista Cerne, Lavras, v. 12, n. 1, p. 56-67, 2006.

SOS. MATA ATLÂNTICA; INPE (Instituto Nacional de Pesquisas Espaciais) Atlas dos remanescentes florestais da Mata Atlântica período de 2008-2010. São Paulo: Fundação SOS Mata Atlântica \& INPE, 2010. $120 \mathrm{p}$.

SYSTAT. 2002. Systat ${ }^{\circledR}$ for Windows ${ }^{\circledR}$ version 10.2 [S.1.]: @ Systat Software.

TABARELLI, M.; MANTOVANI, W. A regeneração de uma floresta tropical. Revista Brasileira de Biologia, São Carlos, v. 59, n. 2, p. 239-250, 1999. http://dx.doi.org/10.1590/S0034-71081999000200008

TONIATO, M. T. Z.; OLIVEIRA-FILHO, A. T. Variations in tree community composition and structure in a fragmento of tropical semideciduous forest in southeastern Brazil related to different human disturbance histories. Forest Ecology and Management, Netherlands, v. 198, n. 1/3, p. 319-339, 2004.

http://dx.doi.org/10.1016/j.foreco.2004.05.029

TROPICOS. Missouri Botanical Garden, 2010. Disponível em: http://www.tropicos.org. Acessado em: 2 jun 2010.

TURNER, I. M. Species loss in fragments of tropical rain forest: a review of the evidence. Journal of Applied Ecology, London, v. 33, n. 2, p. 200-209, 1996. http://dx.doi.org/10.2307/2404743

TURNER, M. G. Landscape ecology: what is the state of the Science? Annual Review Ecology Evolution and Systematics, California, v. 36, p. 319-344, 2005. http://dx.doi.org/10.1146/annurev.ecolsys.36.102003.152614

VIANA, V. M.; TABANEZ, A. A. J.; BATISTA, J. L. F. Dynamics and restoration of Forest fragments in the Brazilian Atlantic moist forest. In: LAURANCE, W. F.; BIERRERGAARD, R. O. (Ed). Tropical forest remnants - ecology, management and conservation of fragmented communities. Chicago: University of Chicago Press, 1997. p. 351-365.

ZAR, J. H. Biostatistical analysis. New Jersey, Prentice Hall, 1984. 718 p. 